\title{
Effects of Passiflora edulis (Yellow Passion) on Serum Lipids and Oxidative Stress Status of Wistar Rats
}

\author{
Maricelma da Silva Soares de Souza, ${ }^{1,2}$ Sandra Maria Barbalho, ${ }^{3,4}$ Débora Cristina Damasceno, ${ }^{2}$ \\ Marilza Vieira Cunha Rudge, ${ }^{2}$ Kleber Eduardo de Campos, ${ }^{5}$ Ana Carolina Goyos Madi, \\ Bruno Ribeiro Coelho, ${ }^{1}$ Rodrigo César Oliveira, Rodrigo Cartaxo de Melo, \\ and Vinícius Castrequini Donda ${ }^{1}$
}

Departments of ${ }^{1}$ Pharmacology and ${ }^{3}$ Biochemistry, School of Medicine and Health Sciences, University of Marília, Marília, São Paulo, Brazil.

${ }^{2}$ Laboratory of Experimental Research of Gynecology and Obstetrics, Department of Gynecology and Obstetrics, Botucatu Medicine School, São Paulo State University, Botucatu, São Paulo, Brazil. ${ }^{4}$ Department of Food Research, Faculty of Food and Technology of Marília, Marília, São Paulo, Brazil.

${ }^{5}$ Institute of Sciences and Health, Mato Grasso Federal University, Sinop, Mato Grasso, Brazil.

\begin{abstract}
The aim of this study was to evaluate the effects of Passiflora edulis f. flavicarpa Degener (yellow passion) juice on the lipid profile and oxidative stress status of Wistar rats. Adult male Wistar rats were divided in two groups $(n=8$ animals per group): the control group, which received water, and the treated group, which was given $P$. edulis juice $(1,000 \mathrm{mg} / \mathrm{kg})$. Both groups received by gavage treatment twice a day for 28 days. The treated group showed an increased high-density lipoproteincholesterol level and decreased low-density lipoprotein-cholesterol and free fatty acid levels compared with the control group. Levels of triglycerides and and very low-density lipoprotein-cholesterol, superoxide dismutase activity, and total glutathione concentration were not statistically different between the two groups, but the thiobarbituric acid-reactive substances concentration (indicating lipid peroxidation) decreased in the treated group. These findings suggests that $P$. edulis juice in the experimental conditions used showed beneficial effects on lipid profile and improved lipid peroxidation in Wistar rats.
\end{abstract}

\section{KEY WORDS: • cholesterol $\bullet$ lipids $\bullet$ oxidative stress $\bullet$ Passiflora edulis $\bullet$ rat}

\section{INTRODUCTION}

$\mathbf{M}$ ANY PLANTS ARE KNOWN and widely used as drugs for the treatment of many diseases, including type 2 diabetes mellitus and high levels of serum lipids. Several studies have shown that many commonly used plants have significant beneficial effects. ${ }^{1-3}$ According to the World Health Organization, about $80 \%$ of the people in the world use medicinal herbs to treat and prevent diseases instead of primary medical assistance because of low prices and the ease of obtaining such medicinal plants. ${ }^{4}$

Literature data confirm the significant effects of alternative medicine to control hyperglycemia ${ }^{5,6}$ and lipid levels. ${ }^{7-9}$

Hypercaloric diets are very common nowadays and increase the occurrence of hypercholesterolemia and low levels of high-density lipoprotein-cholesterol (HDL-c), resulting in higher risks of cardiovascular diseases. ${ }^{10} \mathrm{Hy}-$ percholesterolemia and low HDL-c levels may be associated

Manuscript received 24 February 2011. Revision accepted 1 June 2011.

Address correspondence to: Profa. Dra. Maricelma da Silva Soares de Souza, University of Marília, Rua José Bertonha, 78, Jardim Tangará, CEP 17516-010, Marília, SP, Brazil, E-mail: maricelma.soares.souza@gmail.com with endothelium dysfunction and inflammation, which are often followed by atherosclerosis. The endothelial dysfunction may be prevented by controlling serum lipids. ${ }^{11}$ High levels of total cholesterol, low-density lipoproteincholesterol (LDL-c), and triglycerides associated with lower HDL-c levels may also induce insulin resistance. These parameters together may be conducive to the occurrence of the metabolic syndrome, which increases the risk for development of vascular diseases. ${ }^{12,13}$

The genus Passiflora is largely found in Brazil and include several native plants known as maracujá (yellow passion), but only two of them have commercial importance: Passiflora edulis, usually called juice maracujá, and Passiflora alata, called sweet maracujá. Passiflora quadrangularis has been shown to have hemolytic activity like hemolysin. ${ }^{14}$ The insoluble fiber fraction derived from $P$. edulis seeds has effects on plasma and hepatic lipids from hamsters. ${ }^{15}$ Passiflora incarnata has anxiolytic effects, and its leaves have antiasthmatic activity. ${ }^{16}$ Biochemical parameters and antioxidant defenses (superoxide dismutase [SOD] and glutathione peroxidase [GSH-Px] activities and total glutathione [GSH-t] and thiobarbituric acid-reactive substances [TBARS] concentrations) were affectedwhen male Wistar rats were treated with 
P. alata ${ }^{17}$ A dry extract of Passiflora has been shown to exert positive effects in the control of glycemia and lipid levels. ${ }^{18-20}$

The aim of the present study was to evaluate the effects of $P$. edulis (yellow passion) juice on serum lipid levels and oxidative stress status of Wistar rats.

\section{MATERIALS AND METHODS}

\section{Extraction of plant material}

$P$. edulis seeds were authenticated by experts from the Botanical Department at our institution (São Paulo State University, Botucatu, SP, Brazil) where a voucher specimen has been deposited. The material was prepared by grinding the pulp, similar to the folk-medicine preparation method. The material was filtered through several layers of gauze, and the extract was divided into aliquots and stored and maintained in a freezer until use. A sample was evaporated to determine the total extract concentration $(150 \mathrm{mg} / \mathrm{mL})$.

\section{Animals}

Wistar rats were obtained from the University of Marília, Marília, SP, Brazil. After a 10-day acclimatization, virgin male Wistar rats, weighing $200 \pm 20 \mathrm{~g}$ each, were maintained under standard conditions of temperature $\left(21 \pm 4^{\circ} \mathrm{C}\right)$ and a 12-hour light/dark cycle, with access to water and food ad libitum. The animals were cared for according to the guidelines of the U.S. National Institutes of Health for the care and use of experimental animals.

\section{Experimental procedure}

The rats received daily treatment by gavage, twice a day (in the morning and in the afternoon), for 28 days. The rats were randomly divided into two experimental groups: the control group $(n=8)$ received vehicle (water), which was also used to dilute the plant extract, and the treated group $(n=8)$ was given a dose of $P$. edulis juice at $1,000 \mathrm{mg} / \mathrm{kg}$ of body weight.

\section{Assay for blood samples}

On day 28 of treatment, the rats were anesthetized with sodium phentobarbital (Penta-Hypnol ${ }^{\circledR}$ [3\%], Agrovet Market S.A., Lima, Peru), and blood was then collected for biochemical analysis. Blood samples were divided in two. One portion of blood put into anticoagulant-free test tubes, kept at low temperature for 30 minutes, and then centrifuged at $1,300 \mathrm{~g}$ for 10 minutes at $4^{\circ} \mathrm{C}$. The supernatant was collected as serum and stored at $-80^{\circ} \mathrm{C}$ for determination of the lipid profile. The other portion of blood put into anticoagulant tubes was centrifuged at $90 \mathrm{~g}$ for 10 minutes at room temperature for assay of oxidative stress status.

\section{Assays for oxidative stress status}

The biomarkers estimated for oxidative stress were SOD, GSH-t, GSH-Px, and TBARS as an index of lipid peroxidation.

Lipid peroxides were estimated in the washed erythrocytes using thiobarbituric acid. In brief, $1.0 \mathrm{~mL}$ of washed erythrocytes was added to a test tube containing $1.0 \mathrm{~mL}$ of $3.0 \%$ sulfosalicylic acid, agitated for 10 seconds, centrifuged at $18,000 \mathrm{~g}$ for 3 minutes, and allowed to rest for 15 minutes. The sample was diluted to $500 \mu \mathrm{L}$ of $0.67 \%$ thiobarbituric acid solution. The mixture was heated to $80^{\circ} \mathrm{C}$ for 30 minutes, and the absorbance was measured at a wavelength of $535 \mathrm{~nm}$. The results were expressed as nmol of TBARS per gram of hemoglobin $(\mathrm{nmol} / \mathrm{g} \mathrm{Hb}){ }^{21}$

SOD activity was determined from its ability to inhibit the autooxidation of pyrogallol. The reaction mixture $(1.0 \mathrm{~mL})$ consisted of $5.0 \mathrm{~m} M$ Tris ( $\mathrm{pH} 8.0$ ), $1.0 \mathrm{~m} M$ EDTA, double distilled water, and $20 \mu \mathrm{L}$ of sample. The reaction was initiated by the addition of pyrogallol (final concentration, $0.2 \mathrm{mM}$ ), and the absorbance was measured by a spectrophotometer with a wavelength of $420 \mathrm{~nm}\left(25^{\circ} \mathrm{C}\right)$ for $5 \mathrm{~min}$ utes. The enzymatic activity unit was defined as the amount of SOD units able to produce $50 \%$ of pyrogallol oxidation inhibition. All data were expressed in units of SOD per milligram of hemoglobin. ${ }^{21}$

The content of GSH-t, which consists of reduced and oxidized glutathiones, was enzymatically determined using 5,5'-dithiobis(2-nitrobenzoic acid) and glutathione reductase in the presence of a reduced form of NADPH, forming 2-nitro-5-thiobenzoic acid. A mixture consisting of $1,290 \mu \mathrm{L}$ of distilled water, $200 \mu \mathrm{L}$ of Tris- $\mathrm{HCl}$ buffer $(1 M$ [pH 8.0] with $5 \mathrm{mM}$ EDTA), $200 \mu \mathrm{L}$ of $10 \mathrm{IU} / \mathrm{mL}$ glutathione reductase (Sigma, St. Louis, MO, USA), $200 \mu \mathrm{L}$ of $2 \mathrm{mM}$

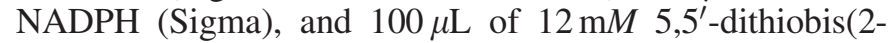
nitrobenzoic acid) (Sigma) was added to $10 \mu \mathrm{L}$ of the sample. Activity was measured at $412 \mathrm{~nm}$ with a spectrophotometer. One unit of activity was equal to $1 \mu \mathrm{mol}$ of substrate reduced per gram of hemoglobin. ${ }^{21}$

GSH-Px activity was assayed by monitoring NADPH oxidation. The mixture consisted in the addition of $1,300 \mu \mathrm{L}$ of distilled water, $200 \mu \mathrm{L}$ of Tris- $\mathrm{HCl}$ buffer ( $1 M$ [pH 8.0] with $5 \mathrm{~m} M$ EDTA), $200 \mu \mathrm{L}$ of $10 \mathrm{IU} / \mathrm{mL}$ glutathione reductase, $200 \mu \mathrm{L}$ of NADPH $(2 \mathrm{mM})$, and $40 \mu \mathrm{L}$ of reduced glutathione $(0.1 M)$ to $40 \mu \mathrm{L}$ of hemolysate. The mixture was agitated in a vortex-mixer for 10 seconds. Next, $20 \mu \mathrm{L}$ of tert-butylhydroperoxide $(7 \mathrm{mM})$ was added and allowed to sit at $37^{\circ} \mathrm{C}$ for 10 minutes. Absorbance was determined with a spectrophotometer at a wavelength of $340 \mathrm{~nm}$. GSHPx activity was expressed in enzymatic activity units (IU) per gram of hemoglobin. ${ }^{21}$

\section{Assay for lipid profile}

Triglycerides, total cholesterol, and HDL-c concentrations were determined with a Wiener Laboratorios S.A.I.C. (Rosário Santa Fé, Argentina) assay kit. ${ }^{22}$

Very LDL-c (VLDL-c) and LDL-c concentrations were determined by the method of Friedewald et al..$^{23}$ Free fatty acids (FFAs) were determined by the Reogun method. ${ }^{24}$

\section{Statistical analysis}

Results are reported as mean \pm SD values. All data were statistically analyzed using analysis of variance followed by 
Table 1. Determination of Triglycerides, Cholesterols, and Free Fatty Acids in Blood Sampled from Rats Treated with $P$. edulis Juice Relative to Control Group Levels

\begin{tabular}{lcc}
\hline & Control group & Treated group \\
\hline Triglycerides $(\mathrm{mg} / \mathrm{dL})$ & $195.54 \pm 113.53$ & $180.69 \pm 99.48$ \\
Cholesterol $(\mathrm{mg} / \mathrm{dL})$ & $145.19 \pm 29.35$ & $109.13 \pm 14.66^{*}$ \\
LDL-c $(\mathrm{mg} / \mathrm{dL})$ & $79.00 \pm 43.40$ & $22.71 \pm 16.69^{*}$ \\
HDL-c $(\mathrm{mg} / \mathrm{dL})$ & $27.07 \pm 7.04$ & $50.28 \pm 13.70^{*}$ \\
VLDL-c $(\mathrm{mg} / \mathrm{dL})$ & $39.11 \pm 15.75$ & $36.14 \pm 10.14$ \\
FFAs $(\mathrm{mEq} / \mathrm{L})$ & $1.18 \pm 0.45$ & $0.56 \pm 0.41^{*}$ \\
\hline
\end{tabular}

Data are mean $\pm \mathrm{SD}$ values.

*Value significantly different from the control group (Student's $t$ test using $P \leq .05)$

FFAs, free fatty acids; HDL-c, high-density lipoprotein-cholesterol; LDL-c, low-density lipoprotein-cholesterol; VLDL, very low-density lipoproteincholesterol.

Student's $t$ test. Statistical significance was considered as $P \leq .05 .^{25}$

\section{RESULTS}

Table 1 presents data of assay for triglycerides, total cholesterol, HDL-c, VLDL-c, LDL-c, and FFAs. Rats treated with $P$. edulis juice presented significantly increased HDL-c levels $(50.28 \pm 13.70 \mathrm{mg} / \mathrm{dL}, P \leq .05)$ compared with the control group $(27.07 \pm 7.04 \mathrm{mg} / \mathrm{dL})$. The treatment with $P$. edulis juice produced decreased cholesterol (109.13 \pm $14.66 \mathrm{mg} / \mathrm{dL}, \quad P \leq .05), \quad$ LDL-c $\quad(22.71 \pm 16.69 \mathrm{mg} / \mathrm{dL}$, $P \leq .05)$, and FFAs $(0.56 \pm 0.41 \mathrm{mEq} / \mathrm{L}, P \leq .05)$ relative to the control group $(145.19 \pm 29.35 \mathrm{mg} / \mathrm{dL}, 79.00 \pm 43.40 \mathrm{mg} /$ $\mathrm{dL}$, and $1.18 \pm 0.45 \mathrm{mEq} / \mathrm{L}$, respectively). Treatment with $P$. edulis juice did not significantly alter triglyceride and VLDL-c levels $(P>.05)$.

Table 2 shows results of oxidative stress status. Rats treated with $P$. edulis juice presented no alteration of SOD activity, GSH-Px activity, and GSH-t concentration $(P>.05)$. TBARS levels of the group given $P$. edulis juice were decreased compared with the control group (58.71 \pm 14.69 vs. $75.61 \pm 21.97 \mathrm{nM} / \mathrm{g}$ of hemoglobin, respectively; $P \leq .05)$.

Table 2. Determination of Superoxide Dismutase, Total Glutathione, Glutathione Peroxidase, and Lipid Peroxidation in Blood Sampled from Rats Treated with $P$. edulis Juice Relative to Control Group Levels

\begin{tabular}{lcc}
\hline & Control group & Treated group \\
\hline SOD $(\mathrm{IU} / \mathrm{g}$ of $\mathrm{Hb})$ & $1,482.98 \pm 370.19$ & $1,281.90 \pm 345.84$ \\
GSH-t $(\mu \mathrm{mol} / \mathrm{g}$ of $\mathrm{Hb})$ & $0.44 \pm 008$ & $0.44 \pm 0.09$ \\
GSH-Px $(\mathrm{IU} / \mathrm{g}$ of $\mathrm{Hb})$ & $25.49 \pm 7.61$ & $31.62 \pm 10.40$ \\
TBARS $(\mathrm{nmol} / \mathrm{g}$ of $\mathrm{Hb})$ & $75.61 \pm 21.97$ & $58.71 \pm 14.69^{*}$ \\
\hline
\end{tabular}

Data are mean \pm SD values.

*Value significantly different from the control group (Student's $t$ test using $P \leq .05)$

GSH-Px, glutathione peroxidase; GSH-t, total glutathione; Hb, hemoglobin; SOD, superoxide dismutase; TBARS, thiobarbituric acid-reactive substances.

\section{DISCUSSION}

Changes in serum lipids are important factors in the genesis of vascular disease. These alterations can be associated with dietary patterns and related to insulin resistance, diabetes mellitus, arterial hypertension, stroke, and several types of cancer that are responsible for the increase of premature death. ${ }^{26}$ The role of lipids in the pathogenesis of insulin resistance (related to obesity and/or diabetes mellitus) is one of the most important pathogenic determinants. ${ }^{27}$

There are studies that have used plants for treatment or prevention of hyperlipidemias: soy, ${ }^{28}$ green tea, ${ }^{29} \mathrm{Mal}$ pighia emarginata, ${ }^{30}$ and Ananas comosus. ${ }^{2}$ Tao et al. ${ }^{31}$ showed significant reduction in glycemia, cholesterol, and triglycerides by using a traditional antidiabetic formula prepared with many plants. Adeneye and Adeyemi ${ }^{32}$ found a decrease in lipids and glycemia after using Hunteria umbellata.

The present study demonstrated that $P$. edulis juice increased HDL-c levels and decreased total cholesterol, LDLc, and FFA levels (Table 1). Ramos et al. ${ }^{19}$ used a flour of passion fruit and also found beneficial effects on the lipid profile; the $P$. edulis juice presented relevant changes in lipid profile. The beneficial effect in HDL-c levels may be attributed to the presence of flavonoids in this species. ${ }^{18}$ Investigation using $P$. alata showed altered HDL-c levels in rats, but it did not show changes in LDL-c levels. ${ }^{18}$ This explanation might be extended to the decreased FFA and cholesterol levels in the animals treated with plant juice (Table 1). Nevertheless, treatment with $P$. edulis did not significantly modify the concentrations of triglycerides and VLDL-c. Other authors have suggested that the insoluble fiber-rich fraction prepared from $P$. edulis could potentially be hypocholesterolemic. ${ }^{15,33}$

Many population studies have established a link between dietary intake of antioxidants and a reduced risk of chronic diseases. Antioxidant potential is very important because oxidative stress may be increased in many pathologies. ${ }^{34}$ The increased oxidative stress is related to a hyperproduction of reactive oxygen species such as $\mathrm{O}_{2}^{-}, \mathrm{OH}^{-}$, and $\mathrm{H}_{2} \mathrm{O}_{2}$ or deficiency in the antioxidant defense system consisting of enzymatic (SOD, catalase, and GSH-Px/glutathione reductase systems) and nonenzymatic scavenger components. Mechanisms that contribute to the formation of free radicals may include metabolic stress resulting from changes in energy metabolism, the levels of inflammatory mediators, and the status of antioxidant defense. ${ }^{35,36}$ Our results did not show significant alteration in SOD and GSH-Px activities and GSH-t concentration after treatment with $P$. edulis juice (Table 2). There is increasing evidence that in certain pathological conditions the increased production and/or ineffective scavenging of such reactive species may play a crucial role in determining tissue injury by lipid peroxidation, especially in atherosclerotic and cardiovascular diseases, even in the presence of hypertension, hyperlipidemias, and smoking. ${ }^{37,38}$ In the present study, the TBARS concentration from rats treated with $P$. edulis juice was decreased (Table 2). TBARS are considered a lipid 
peroxidation indicator. ${ }^{39}$ In spite of no alteration in SOD and GSH-Px activities, the decreased TBARS concentration might be the result of action of the nonenzymatic antioxidants present in the plant juice. Passiflora species contain a great amount of lycopene; thus passionflower fruit is considered an alternative source of antioxidant products. ${ }^{40}$ In this way, $P$. edulis juice may be effective in reducing lipid peroxidation and may improve protection to cellular membranes.

In conclusion, $P$. edulis juice showed beneficial effects for the lipid profile because it increased the HDL-c level and decreased levels of LDL-c, cholesterol, and FFAs. In addition, the plant juice decreased the TBARS concentration. These results show that $P$. edulis improved lipid metabolism and oxidative stress status. This study is very important because hyperlipidemia represents a major risk factor to the development of insulin resistance, the metabolic syndrome, and other diseases. However, the demonstration of the active component present in $P$. edulis that is responsible for these beneficial actions needs further investigation.

\section{AUTHOR DISCLOSURE STATEMENT}

No competing financial interests exist.

\section{REFERENCES}

1. Kuo KL, Weng MS, Chiang CT, Tsai YJ, Lin-Shiau SY, Lin JK: Comparative studies on the hypolipidemic and growth suppressive effects of oolong, black, puerh, and green tea leaves in rats. J Agric Food Chem 2005;53:480-489.

2. Xie W, Xing D, Sun H, Wang W, Ding Y, Du L: The effects of Ananas comosus L. leaves on diabetic-dyslipidemic rats induced by alloxan and high-fat/high-cholesterol diet. $\underline{\mathrm{Am} \mathrm{J} \mathrm{Chin} \mathrm{Med}}$ 2005;33:95-105.

3. Borochov-Neori H, Judeinstein S, Greenberg A, Fuhrman B, Attias J, Volkova N, Hayek T, Aviram M: Phenolic antioxidants and antiatherogenic effects of Marula (Sclerocarrya birrea subsp. caffra) fruit juice in healthy humans. J Agric Food Chem 2008;56:9884-9891.

4. Repetto MG, Lleusuy SF: Antioxidant properties of natural compounds used in popular medicine for gastric ulcers. $\underline{\operatorname{Braz} J}$ Med Biol Res 2002;35:532-534.

5. Damasceno DC, Volpato GT, de Mattos Paranhos Calderon I, Aguilar R, Rudge MVC: Effect of Bauhinia forficata extract in diabetic pregnant rats: maternal repercussions. Phytomedicine 2004;11:196-201.

6. Maiti R, Jana D, Das UK, Ghosh D: Antidiabetic effect of aqueous extract of seed of Tamarindus indica in streptozomicininduced diabetic rats. J Ethnopharmacol 2004;92:85-91.

7. Hannan JMA, Rokeya B, Faruque O, Nahar N, Mosihuzzaman M, Azad Khan K, Ali L: Effect of soluble dietary fibre fraction of Trigonella foenum graecum on glycemic, insulinemic, lipidemic and platelet aggregation status of Type 2 diabetic model rats. J Ethnopharmacol 2003;88:73-77.

8. Schaan BDA, Harzheim E, Gus I: Perfil de risco cardíaco no diabetes mellitus e na glicemia jejum alterada. Rev Saúde Publica 2004;38:529-536.

9. Ziaee A, Zamansoltani F, Nassiri-Asl M, Abbasi E: Effects of rutin on lipid profile in hypercholesterolemic rats. Basic Clin Pharmacol Toxicol 2009;104:253-258.
10. Lu J, Borthwick F, Hassanali Z, Wang Y, Mangat R, Ruth M, Shi D, Jaeschke A, Russell JC, Field CJ, Proctor SD, Vine DF: Chronic dietary n-3 PUFA intervention improves dyslipidaemia and subsequent cardiovascular complications in the JCR:LA-cp rat model of the metabolic syndrome. Br J Nutr 2011;105:15721582.

11. Lindqvist HM, Sandberg AS, Fagerberg B, Hulthe J: Plasma phospholipid EPA and DHA in relation to atherosclerosis in 61-year-old men. Atherosclerosis 2008;205:574-578.

12. Hummel S, Pfuger M, Kreichauf S, Hummel M, Ziegler AG: Predictors of overweight during childhood in offspring of parents with type 1 diabetes. Diabetes Care 2009;32:921-925.

13. El Mesallamy HO, El-Demerdash E, Hammad LN, El Magdoub HM: Effect of taurine supplementation on hyperhomocysteinemia and markers of oxidative stress in high fructose diet induced insulin resistance. Diabetol Metab Syndr 2010;2:46.

14. Yuldasheva LN, Carvalho EB, Catanho MT, Krasilnikov OV: Cholesterol-dependent hemolytic activity of Passiflora quadrangularis leaves. Braz J Med Biol Res 2005;38:1061-1070.

15. Chau CF, Huang YL: Effects of the insoluble fiber derived from Passiflora edulis seed on plasma and hepatic lipids and fecal output. Mol Nutr Food Res 2005;49:786-790.

16. Dhawan K, Kumar S, Sharma A: Antiasthmatic activity of the methanol extract of leaves of Passiflora incarnata. Phytother Res 2003;17:821-822.

17. Petry RD, Reginatto F, de-Paris F, Gosmann G, Salgueiro JB, Quevedo J, Kapczinski F, Ortega GG, Schenkel EP: Comparative pharmacological study of hydroethanol extracts of Passiflora alata and Passiflora edulis leaves. Phytother Res 2001;15:162-164.

18. Doyama JT, Rodrigues HG, Novelli EL, Cereda E, Vilegas W: Chemical investigation and effects of the tea of Passiflora alata on biochemical parameters in rats. J Ethnopharmacol 2005;96: 371-374.

19. Ramos AT, Cunha MAL, Sabaasrur AUO, Pires VCF, Cardoso AA, Diniz MF: Use of Passiflora edulis f. flavicarpa on cholesterol reduction. Braz J Pharmacogn 2007;17:592-597.

20. Rudnicki M, Silveira MM, Pereira TV, Oliveira MR, Reginatto FH, Dal-Pizzol F, Moreira JC: Protective effects of Passiflora alata extract pretreatment on carbon tetrachloride induced oxidative damage in rats. Food Chem Toxicol 2007;45:656-661.

21. Ferreira ALA, Machado PEA, Matsubara LS: Lipid peroxidation, antioxidant enzymes and glutathione levels in human erythrocytes exposed to colloidal iron hydroxide in vitro. $\underline{\mathrm{Braz} J \mathrm{Med}}$ Biol Res 1999;32:689-694.

22. Young DS: Effects of Drugs on Clinical Laboratory Tests, 5th ed. AACC Press, London, 2000.

23. Friedewald WT, Levy RI, Fredrickson DS: Estimation of the concentration of low density lipoprotein cholesterol in plasma, without use of the preparative centrifuge. Clin Chem 1972;18: 499-502.

24. Moura RA: NEFA (Ácidos graxos livres). In: Técnicas de Laboratório. Atheneu, São Paulo, 2002, pp. 63-64.

25. Zar JH: Biostatistical Analysis, 4th ed. Prentice Hall, Upper Saddle River, NJ, 1999.

26. Mäkinen VP, Forsblom C, Thorn LM, Wadén J, Gordin D, Heikkilä O, Hietala K, Kyllönen L, Kytö J, Rosengård-Bärlund M, Saraheimo M, Tolonen N, Parkkonen M, Kaski K, AlaKorpela M, Groop PH: Metabolic phenotypes, vascular complications, and premature deaths in a population of 4,197 patients with type 1 diabetes. Diabetes 2008;57:2480-2487. 
27. Zeman M, Jirak R, Jachymova M, Vecka M, Tvrzicka E, Zak A: Leptin, adiponectin, leptin to adiponectin ratio and insulin resistance in depressive women. Neuro Endocrinol Lett 2009;30: 387-395.

28. Eilat-Adar S, Goldbourt U: Nutritional recommendations for preventing coronary heart disease in women: evidence concerning whole foods and supplements. Nutr Metab Cardiovasc Dis 2010;20:459-466.

29. Ramadan G, El-Beih NM, Abd El-Ghffar EA: Modulatory effects of black v. green tea aqueous extract on hyperglycaemia, hyperlipidaemia and liver dysfunction in diabetic and obese rat models. Br J Nutr 2009;102:1611-1619.

30. Barbalho SM, Damasceno DC, Spada AP, Palhares M, Martuchi KA, Oshiiwa M, Sazaki V, da Silva VS: Evaluation of glycemic and lipid profile of offspring of diabetic Wistar rats treated with Malpighia emarginata juice. Exp Diabetes Res 2011;2011: 173647.

31. Tao W, Deqin Z, Yuhong L, Hong L, Zhanbiao L, Chunfeng Z, Limin H, Xiumei G: Regulation effects on abnormal glucose and lipid metabolism of TZQ-F, a new kind of Traditional Chinese Medicine. J Ethnopharmacol 2010;128:575-582.

32. Adeneye $\mathrm{AA}$, Adeyemi OO: Further evaluation of antihyperglycaemic activity of Hunteria umbellata (K. Schum) Hallier

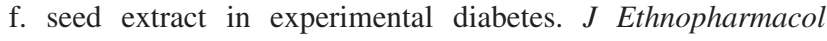
2009;126:238-243.
33. Yapo BM, Koffi KL: Dietary fiber components in yellow passion fruit rind-a potential fiber source. J Agric Food Chem 2008; 56:5880-5883.

34. Barbosa KBF, Bressan J, Zulet MA, Martinez JA: Influence of dietary intake on plasma biomarkers of oxidative stress in humans [in Spanish]. An Sis Sanit Navar 2008;31:259-280.

35. Halliwell B, Gutteridge JMC: Free Radicals in Biology and Medicine, 3rd ed. Oxford University Press, Oxford, 1999.

36. Danielsen PH, Møller P, Jensen KA, Sharma AK, Wallin H, Bossi R, Autrup H, Mølhave L, Ravanat JL, Briedé JJ, de Kok TM, Loft S: Oxidative stress, DNA damage, and inflammation induced by ambient air and wood smoke particulate matter in human A549 and THP-1 cell lines. Chem Res Toxicol 2011;24: 168-184.

37. Souza MSS, Sinzato YK, Lima PH, Calderon IM, Rudge MV, Damasceno DC: Oxidative stress status and lipid profiles of diabetic pregnant rats exposed to cigarette smoke. Reprod Biomed Online 2010;20:547-552.

38. Heusch G, Schulz R: A radical view on the contractile machinery in human heart failure. J Am Coll Cardiol 2011;57:310-312.

39. Kim HK, Kim MJ, Lyu ES, Shin DH: Improvement of diabetic complication by Hydrangea Dulcis Folium in streptozotocininduced diabetic rats. Biol Pharm Bull 2009;32:153-156.

40. Mourvaki E, Gizzi S, Rossi R, Rufini S: Passionflower fruit a new source of lycopene? J Med Food 2005;8:104-106. 


\section{This article has been cited by:}

1. Eliziane Mieko Konta, Mara Ribeiro Almeida, Cátia Lira do Amaral, Joana Darc Castania Darin, Veridiana V. de Rosso, Adriana Zerlotti Mercadante, Lusânia Maria Greggi Antunes, Maria Lourdes Pires Bianchi. 2013. Evaluation of the Antihypertensive Properties of Yellow Passion Fruit Pulp ( Passiflora edulis Sims f. flavicarpa Deg.) in Spontaneously Hypertensive Rats. Phytotherapy Research n/a-n/a. [CrossRef]

2. Juliana Kelly da Silva, Cinthia Baú Betim Cazarin, Talita C. Colomeu, Ângela Giovana Batista, Laura M.M. Meletti, Jonas Augusto Rizzato Paschoal, Stanislau Bogusz Júnior, Mayra Fontes Furlan, Felix Guillermo Reyes Reyes, Fábio Augusto, Mário Roberto Maróstica Júnior, Ricardo de Lima Zollner. 2013. Antioxidant activity of aqueous extract of passion fruit (Passiflora edulis) leaves: In vitro and in vivo study. Food Research International . [CrossRef]

3. Sandra Maria Barbalho, Maricelma da Silva Soares de Souza, Patrícia Cincotto dos Santos Bueno, Élen Landgraf Guiguer, Flávia Maria Vasques Farinazzi-Machado, Adriano Cressoni Araújo, Carla Omete Meneguim, Eliane Pascoal Silveira, Natalia de Souza Oliveira, Beatriz Clivati da Silva, Sara da Silva Barbosa, Claudemir Gregório Mendes, Priscilla Rodrigues Gonçalves. 2012. Annona montana Fruit and Leaves Improve the Glycemic and Lipid Profiles of Wistar Rats. Journal of Medicinal Food 15:10, 917-922. [Abstract] [Full Text HTML] [Full Text PDF] [Full Text PDF with Links] 